\title{
A Listening Tour: Conversations about Obamacare across America's Heartland
}

\author{
Paul R. Gordon, MD, MPH
}

During my sabbatical, I rode my bike 3300 miles from Washington, DC, to Seattle, WA, in order to engage in dialog with people along the northern tier of America's heartland. Through informal and candid conversations with $>100$ people, I gained insights into attitudes and opinions about the Patient Protection and Affordable Care Act (Obamacare). The comments were overwhelmingly negative. In this reflective essay, I share some of the conversations I had and the insights I gained from this remarkable journey across our beautiful country. (J Am Board Fam Med 2017;30:544-546.)

Keywords: Bicycling, Patient Protection and Affordable Care Act

As I rode my bike from small-town café to a variety of mom-and-pop restaurants that all had delicious smells emanating from their homey kitchens, the comments all began sounding the same: "So Obama's paying you to ride your bike across the country to convince me and my family his insurance plan is a great idea?," one middle-aged man from a small town in western Maryland said after a short introductory discussion we had near the bike path I was riding on that day. "Good luck with that, man. And good luck with the rest of your ride. I hope you get the answers you are looking for. But not me, I hate the plan."

A somewhat older gentleman in Ohiopyle, PA, another small town I passed through early in my long-planned sabbatical, told me, "I don't like it because I have to pay for those who do not work. People ought to be paying their fair share." Along the shores of Lake Michigan, John told me that "It is wrong for the government to tell me to buy insurance for things I don't believe in. I don't believe in abortion, so why do I have to pay for

This article was externally peer reviewed.

Submitted 27 February 2017; revised 2 March 2017; accepted 13 March 2017.

From the Department of Family and Community Medicine, University of Arizona College of Medicine, Tucson, AZ.

Funding: none.

Conflict of interest: none declared.

Corresponding author: Paul R. Gordon, MD, MPH, Department of Family and Community Medicine, University of Arizona College of Medicine, 1501 N. Campbell, AHSC, Box 24-5113, Tucson, AZ 85724-5113 (E-mail: pgordon@ u.arizona.edu). that?" I tried to tell him that the Patient Protection and Affordable Care Act (ACA) does not require insurance companies to pay for abortion; he insisted that I was wrong and that it was exactly the opposite.

As I rode into America's heartland, I found that not only the crotchety old men and women who had been hardened by the landscape expressed what I dishearteningly saw as a general self-centeredness fueled by an apparent lack of consideration. It was Mr. and Mrs. Every Town American. Like Helen, the barkeep from northern Ohio. She called the president a liar, even when I pressed her on the details of her complaints and explained that perhaps it was the insurance companies that were limiting access to further their own interests. "Obama said I could keep my doctor and he lied," she reiterated at the end of the heated conversation that left me discouraged and a little bit angry.

These negative comments, almost exclusively from the people who had not received a subsidy from the ACA, made up the majority of the comments I heard. But there were positive comments as well. As we sat across from each other enjoying a piece of huckleberry pie in western Wisconsin, Jack, a self-identified progressive, told me that the ACA had done a good job. This belief, he shared with me, stemmed from his values of social justice. Susan told me about her sister in Minnesota who would have died from breast cancer had it not been for her new insurance through the ACA. However, these positive comments were the minority. 
What astonished me as I rode from one small town in America to the next was what seemed to me to be a general lack of compassion from people who, for the most part, seemed cordial and supportive on the outside--even supportive of a guy like me, who they probably realized did not share their views. It was a lack of concern for the class of clientele the ACA was established to help-people who, for whatever reason, did not have access to basic health care.

As the ride became more onerous in the open plains of the Midwest and the tremendous climbs through the Rockies, I began to get a little depressed. Trying to ignore the politics I had found myself caught up in, I delved more into the challenges of the ride, remembering as I pedaled along what it was that had drawn me to the trip in the first place. I'd always dreamed about cycling across the country and discovering parts of America I had never seen before, the challenge of completing an unaided 3300-mile bicycle trek 5 years after undergoing open-heart surgery to replace my aortic arch and repair my bicuspid aortic valve. And a great opportunity to tie this personal goal to my professional interest of finding out information about peoples' thoughts about our health care system that might change the way we as practitioners think about our work.

It is about the journey, a friend had told me, as I rode through strong headwinds and the occasional hail storm into sunshine that lit up a beautifully changing countryside. For the first time in my life, I had time to appreciate the true natural beauty of our country and the diversity of the people who lived in these different communities. Stroke by stroke, from one rustic farm to the next, up one hill and then down, the ride gave me time to reflect not only on my current experience but also on where I have been personally and where my career was headed - moments of reflection that last a sliver of time in the fast pace of our ritualistic American lives, but that out on the lonely road turn into hours of peaceful, wholesome solitude.

Then, almost two thirds of the way through my journey, I met a Marlon Brando-type biker outside a bar in the dusty town of Manchester, SD, a guy with a scraggly beard and a bunch of intimidating tattoos covering his thick muscular arms. "Pretty tough headwinds, don't you think?" he said as we both readied to leave on our respective means of transportation. "You just got to lean into it," he said, looking at the motor on his Harley. "Crank her up to 85 . That'll get you through those winds."

I did not say anything, and for a second it seemed as though the two of us might ride off into the sunset together, but then he looked down at the bike I was riding-loaded to the hilt with panniers bulging with all my supplies-and slowly shook his head. "Well, maybe not so much," he said, starting his motor and revving the engine. "Not enough horsepower on that engine of yours." Then he laughed. "See you on the road, dude!" And with that he rode off, leaving me standing in the dust of his wake, my feelings not hurt, but instead emboldened by the knowledge that I already had the horsepower he was talking about: the strength, both physical and emotional, to finish the journey and use the insights I was slowly gleaning in my work as a clinician and teacher.

No one had offered a solution to the ills of the ACA, nor did I have enough information to make any particular claims about the state of our health care system, but as a family doctor who had for a long time practiced a "people" kind of primary care medicine, I'd always prided myself as a guy who could sit down with anyone and listen to what they had to say; the type of doctor a patient is comfortable having across the examination table from them. And that is what I came to appreciate on this amazing ride. Not that I could get all the answers, and not that I could change people's minds, but rather that if I listened attentively, people would candidly share their stories without fear of being interrupted or judged.

In the final stages of the ride that would eventually take me into the beautiful lush scenery of the upper northwest, I had the chance to reflect on the stories I heard and the people I met. The depressed thoughts I had from my initial encounters eventually gave way to a new sense of resolve. A resolve to work with my students to help them work with their patients to develop a deeper understanding of their feelings and their needs-just like I had done on my bike trip.

The majority voice of negativity toward the ACA was understandable. These people hadn't benefited from its largesse. They were the ones outside of $400 \%$ of the federal poverty limit who did not qualify for subsidies. They were the ones from the small towns with prior insurance policies that did not meet the ACA's minimum standards, who had to change their policy, and, in an effort to 
maintain low premiums, had their networks narrowed and the deductible rise exorbitantly. They were not ill and were angry that the ACA mandated a more expensive insurance policy. Although unfortunate, I came to understand how they directed their anger at that unknown other. Understandable perhaps, but not in keeping with our deeply held values of compassion toward those less fortunate. Whatever solutions arise in the ACA's aftermath, I will work to ensure that they will demonstrate our values of compassion and will listen to all these voices and stories.

Having heard these many negative comments, I would look forward to a similar ride on which I used the same attentive listening skills, but next time to a country with publically supported, universal health care coverage whose citizens have a more compassionate view that recognizes that caring for each other makes a stronger nation.

(All informants were deidentified by name and gender. Pseudonyms were used to protect anonymity.)

The author thanks Dr. Ron Grant for guidance in the writing of this article.

To see this article online, please go to: http://jabfm.org/content/ 30/4/544.full. 